\title{
Isolated cerebral Aspergillus granuloma with no obvious source of infection
}

\author{
Sundaram Challa, Shantveer G. Uppin, Anirudh K. Purohit* \\ Departments of Pathology and *Neurosurgery, Nizam's Institute of Medical Sciences, Punjagutta, Hyderabad - 500 082, AP, India
}

\begin{abstract}
Background: Intracranial fungal granulomas occur by extension from contiguous structures or by hematogenous dissemination from lungs. Isolated granulomas without any obvious source of infection are extremely uncommon. Objective: To describe isolated intracerebral Aspergillus spp. granuloma without any obvious source of infection. Materials and Methods: We analyzed clinical, radiological and pathological features of isolated intracerebral aspergillus granulomas diagnosed in our institution between 1986 and 2006. The chest X-ray and paranasal sinus (PNS) X-rays were reviewed. Fungal stainings were done on histological sections. Results: We identified eight patients with Aspergillus spp. intracerebral granulomas (six males, two females). There were no predisposing risk factors. The chest and PNS Xrays were normal. On computerized tomography all were heterogeneously enhancing lesions with perilesional edema. Pre or perioperative diagnosis was never made. Histological studies revealed granulomas with minimal fibrosis and giant cells and septate hyphae of Aspergillus spp. on fungal stains. Two patients died of postoperative complications and two patients relapsed. Conclusion: Isolated intracerebral aspergillus granulomas are rare and pose a diagnostic challenge. Fungal granulomas should be considered in the differential diagnosis of intracerebral inflammatory pathologies.
\end{abstract}

Key words: Aspergillus, fungal granuloma, intracerebral

Intracranial fungal granulomas are uncommon, but surgically treatable lesions. ${ }^{[1-5]}$ Most often, the fungal granulomas are due to contiguous spread of the infection from the paranasal sinuses and ear. Rarely, they may be due to hematogenous spread from a focus in the lungs. ${ }^{[3-7]}$ Isolated cerebral fungal granulomas without any obvious extracranial focus of infection are extremely uncommon $^{[7]}$ and have not received much attention in the literature. This paper presents eight patients with isolated cerebral aspergillus granulomas without obvious extracranial source of infection and discusses the diagnostic challenges.

\section{Materials and Methods}

Case records of patients with biopsy/autopsy confirmed intracranial Aspergillus spp. granulomas from January 1986 to December 2006 available in the Department of Pathology, Nizam's Institute of Medical Sciences, Hyderabad, were reviewed. The data collected included demographic data, clinical characteristics, imaging findings, treatment and outcome. Patients with isolated cerebral aspergillus granuloma without obvious source of infection, as evaluated by imaging studies were included in the study. Histological slides were reviewed for the type of tissue reaction and fungal morphology. Histochemical stains studied included hematoxylin and eosin ( $\mathrm{H}$ and $\mathrm{E}$ ), Gomori's silver methenamine (GMS) and periodic acid Schiff (PAS). Culture reports were collected whenever material was submitted for culture.

\section{Results}

During the study period of 19 years, there were 86 patients with intracranial fungal granulomas, of which $13(15.1 \%)$ were only intracerebral (i.e. no extracerebral lesions). Of them, eight (61.5\%) were Aspergillus spp. granulomas. These accounted for $9.6 \%$ of 83 Aspergillus spp. granulomas seen during the study period. The clinical characteristics, radiological features, and outcome are given in Table 1.

None of the patients had any predisposing risk factors and all were deemed immuno-competent. The duration of symptoms ranged from one to three months. All the granulomas were supratentorial in location, seven in the right hemisphere and one in the left hemisphere. On computerized tomography (CT) scan, all of them were heterogeneously enhanced lesions with perilesional edema [Figure 1]. In none of the patients, the diagnosis was suspected preoperatively and/or peroperatively.

The pathology was granulomas with predominance of foreign body giant cells, some of which showed negative 
Table 1: Clinical features, radiological characteristics and outcome

\begin{tabular}{|c|c|c|c|c|c|}
\hline $\begin{array}{l}\text { Genderl } \\
\text { Age (year) }\end{array}$ & $\begin{array}{l}\text { Duration } \\
\text { (months) }\end{array}$ & Clinical picture & $\begin{array}{l}\text { Contrast CT and preoperative } \\
\text { diagnosis }\end{array}$ & $\begin{array}{l}\text { PNS X-ray } \\
\text { chest X-ray }\end{array}$ & Outcome \\
\hline $\mathrm{M} / 40$ & 3 & $\begin{array}{l}\text { Difficulty in walking, headache, } \\
\text { vomiting, giddiness - bilateral mild } \\
\text { papilledema and left hemiparesis }\end{array}$ & $\begin{array}{l}\text { Heterogeneously enhancing right } \\
\text { frontal lesion with perilesional } \\
\text { edema - Glioma }\end{array}$ & Normal & $\begin{array}{l}\text { Postoperative } \\
\text { dissemination and death }\end{array}$ \\
\hline $\mathrm{M} / 74$ & 2 & $\begin{array}{l}\text { Headache, left side limb weakness } \\
\text { - left hemiparesis }\end{array}$ & $\begin{array}{l}\text { Heterogeneously enhancing } \\
\text { right parieto-temporal lesion with } \\
\text { perilesional edema and mass } \\
\text { effect - Glioma }\end{array}$ & Normal & $\begin{array}{l}\text { Started on Amphotericin B; } \\
\text { lost to follow-up after } 1 \text { year }\end{array}$ \\
\hline $\mathrm{M} / 7$ & 1 & $\begin{array}{l}\text { Headache, seizures, left side } \\
\text { weakness - left hemiparesis }\end{array}$ & $\begin{array}{l}\text { Faintly enhancing right frontal } \\
\text { lesion with perilesional edema } \\
\text { - Glioma }\end{array}$ & Norm & $\begin{array}{l}\text { Postoperative } \\
\text { complications and death }\end{array}$ \\
\hline$M / 30$ & 2 & $\begin{array}{l}\text { Headache, left focal seizures, left } \\
\text { upper motor neuron facial palsy, } \\
\text { left hemiparesis }\end{array}$ & $\begin{array}{l}\text { Heterogeneously enhancing } \\
\text { right fronto-temperoparietal } \\
\text { lesion with perilesional edema } \\
\text { - Glioblastoma }\end{array}$ & & Recurred after 1 year \\
\hline$M / 27$ & 2 & $\begin{array}{l}\text { Right occipital headache, decrease } \\
\text { of vision - left hemi-field defect }\end{array}$ & $\begin{array}{l}\text { Heterogeneously enhancing } \\
\text { right occipito-parietal lesion with } \\
\text { perilesional edema - Glioma }\end{array}$ & & $\begin{array}{l}\text { Recurrence of symptoms } \\
\text { after } 4 \text { months }\end{array}$ \\
\hline$F / 16$ & 2 & $\begin{array}{l}\text { Fever, seizures headache, } \\
\text { vomiting, weakness on left side of } \\
\text { body - bilateral papilledema, left } \\
\text { hemiparesis }\end{array}$ & $\begin{array}{l}\text { Right parietal lesion with patchy } \\
\text { enchancement with perilesional } \\
\text { edema - Glioma }\end{array}$ & Normal & $\begin{array}{l}\text { Started on Amphotericin } \\
\text { B; lost to follow-up after } 10 \\
\text { months }\end{array}$ \\
\hline$M / 55$ & 3 & $\begin{array}{l}\text { Headache, vomiting, weakness of } \\
\text { left side of body }\end{array}$ & $\begin{array}{l}\text { Heterogeneously enhancing right } \\
\text { parietal lesion with perilesional } \\
\text { edema - Glioma }\end{array}$ & Normal & $\begin{array}{l}\text { Started on Amphotericin } \\
\text { B; lost to follow-up after } 6 \\
\text { months }\end{array}$ \\
\hline $\mathrm{F} / 60$ & 2 & $\begin{array}{l}\text { Fever, headache - bilateral } \\
\text { papilledema - }\end{array}$ & $\begin{array}{l}\text { Heterogeneously enhancing left } \\
\text { temporal lesion with perilesional } \\
\text { edema - Glioma }\end{array}$ & Normal & $\begin{array}{l}\text { Started on Amphotericin B; } \\
\text { lost to follow-up after } 1 \text { year }\end{array}$ \\
\hline
\end{tabular}

PNS - Paranasal sinus

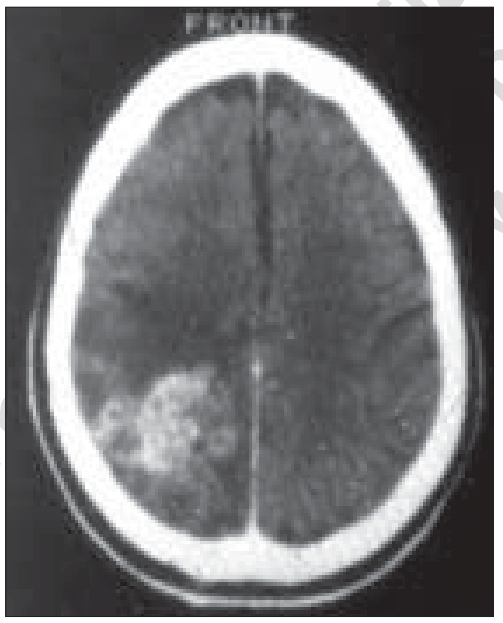

Figure 1: Contrast CT of brain showing multiple conglomerate ring and patchy enhancement with perilesional edema in the right parietal cortex with extension into centrum semi-ovale

staining structures within the cytoplasm in all the eight patients [Figure 2]. Fibrosis was minimal. Gomori's silver methenamine stain delineated narrow septate acute angle branching hyphae [Figure 3]. Based on the morphological characteristics in the histological sections the fungus was typed as Aspergillus spp. Material was submitted for culture in one patient at autopsy which grew Aspergillus niger.
All the patients were started on amphotericin B after the diagnosis was obtained. Two patients died postoperatively. Complete autopsy was done in one of them for whom the pathology was disseminated within the brain [Figure 2]. No source of infection was identified, even at autopsy, in the rest of the body and contiguous structures. In two patients, there was recurrence of lesion. Four patients were followed up until six months to one year. No subsequent follow-up was available.

\section{Discussion}

The preoperative diagnosis of isolated Aspergillus spp. granuloma without an obvious source of infection is quite challenging. ${ }^{[7]}$ In none of the patients in the present study the diagnosis of Aspergillus spp. granuloma was suspected preoperatively and intra-operatively. This had resulted in: i) non-submission of the biopsy material for fungal cultures; ii) unnecessary exposure to steroid treatment. There is a possibility of dissemination with steroid exposure as had probably happened in one of our patients.

In the reported series of fungal granulomas the longterm outcome was poor and total cure was achieved in only a few cases..$^{[2,4,8]}$ Sharma et al. reported six patients in whom the granulomas were located within the brain 


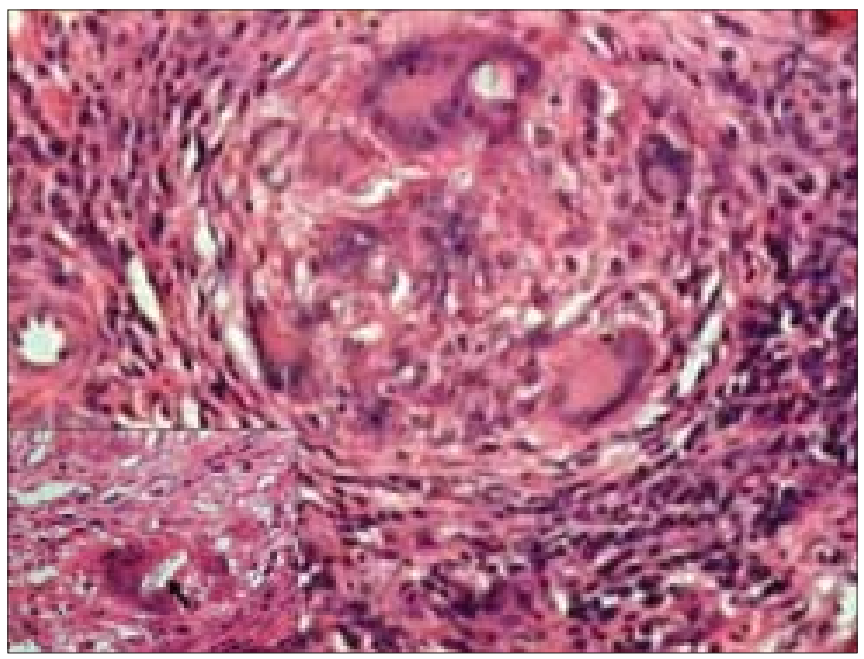

Figure 2: Photomicrograph showing granuloma composed of epithelioid cells and giant cells with peripheral lymphocytes and plasma cells. Inset shows giant cell with intracytoplasmic negative staining structures (black arrow). (H \& E, x10)

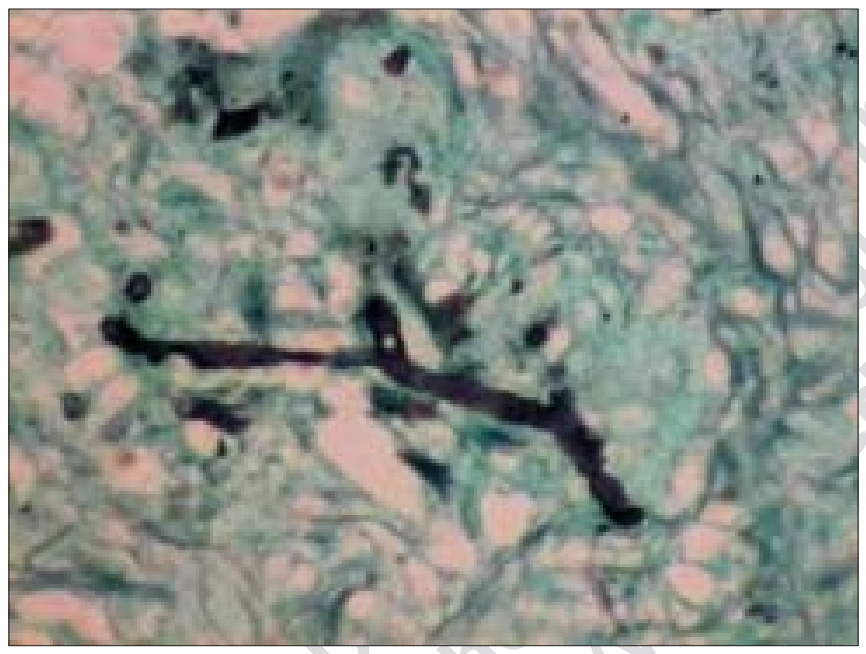

Figure 3: Photomicrograph showing narrow septate acute angle branching hyphae of Aspergillus spp. (Gomori's methenamine silver, x40)

parenchyma. ${ }^{[2]}$ Three of them had ear discharge. Sharma et al. compared the differentiating features between the rhinocerebral and primary intracranial group of patients and concluded that the latter had high mortality due to delayed diagnosis. Surgical intervention with antifungal treatment is crucial in the management of CNS fungal granulomas. ${ }^{[2]}$ For fungal granuloma, the treatment options for complete cure are total or near total surgical excision and antifungal treatment. Often, as these lesions are not suspected preoperatively and intraoperatively, the surgical excision may not be optimal as happened in two of our patients.

Isolated cerebral Aspergillus granuloma without obvious source of focus of infection is extremely rare. ${ }^{[7]}$ The possible source of infection in these patients is speculative and may be an undetectable small focus of infection in the paranasal sinuses or in the lungs. In all the patients reported herein, we were not able to find an extracerebral infectious focus. For the patient who underwent autopsy, we looked carefully for any focus in the lung, heart and other organs. Our conjuncture is that in patients with frontal and temporal location of the lesion, the portal of entry may be the paranasal sinuses and the ears, respectively. In patients with parietal lesions, the spread may be hematogenous.

In tropical countries from where Aspergillus spp. granulomas are more frequently described, any isolated mass lesion with imaging characteristics of inflammatory pathology should raise the possibility of fungal granuloma. Such an approach is likely to result in an early diagnosis and may avoid poor outcome.

\section{References}

1. Haran RP, Chandy MJ. Intracranial Aspergillus granuloma. $\mathrm{Br} J$ Neurosurg 1993; 7:383-8

2. Sharma BS, Khosla VK, Kak VK, Banerjee AK, Vasishtha RK, Prasad KS, et al. Intracranial fungal granuloma. Surg Neurol 1997;47:48997.

3. Murthy JM, Sundaram C, Prasad VS, Purohit AK, Rammurthi S, Laxmi V. Aspergillosis of central nervous system. A study of 21 patients seen in University Hospital, South India. JAPI 2000;48:677-81.

4. Murthy JM, Sundaram C, Prasad VS, Purohit AK, Rammurthi S, Laxmi V. Sinocranial aspergillosis: A form of central nervous system aspergillosis in South India. Mycoses 2001;44:141-5.

5. Dubey A, Patwardhan RV, Sampath S, Santosh V, Kolluri S, Nanda A. Intracranial fungal granuloma: Analysis of 40 patients and review of the literature. Surg Neurol 2005;63:254-60.

6. Santosh V, Yasha TC, Khanna N, Pal L, Swamy HS, Chandramuki A, et al. Fungal infections of the nervous system - pathological study. Neurol Infect Epid 1996;1:69-79.

7. Sundaram C, Umabala P, Laxmi V, Purohit AK, Prasad VS, Panigrahi M, et al. Pathology of fungal infections of the central nervous system: 17 years experience from Southern India. Histopathology 2006;49:396-405.

8. Naim-Ur-Rahman, Jamjoom A, al-Hedaithy SS, Jamjoom ZA, alSohaibani MO, Aziz SA. Cranial and intracranial aspergillosis of sinonasal origin. Report of nine cases. Acta Neurochir (Wien) 1996;138:944-50.

Accepted on 11-05-2007

Source of Support: Nil, Conflict of Interest: None declared. 